Revista Iberoamericana, Vol. LXVIII, Núm. 201, Octubre-Diciembre 2002, 1067-1080

\title{
LA PATOLOGÍA DE LA AFRICANÍA EN DEL AMOR Y OTROS DEMONIOS DE GARCÍA MÁRQUEZ*
}

POR

\author{
Margaret M. Olsen \\ University of Missouri-Columbia
}

Como otras novelas de García Márquez, Del amor y otros demonios vuelve al pasado de América Latina para encontrar allí su espacio narrativo, los motivos para la creación de sus personajes y el origen de su temática. También como en otras novelas del escritor colombiano, el paisaje donde se desarrolla la historia es de decadencia, enfermedad y alienación. Lo particular de esta novela, sin embargo, es la constante presencia africana en sus páginas. Mientras García Márquez ha propuesto que la realidad cultural de Colombia se basa en gran parte en la tradición africana, Del amor y otros demonios es su primera obra narrativa en la que la cultura africana ocupa una posición tan central y explícita. ${ }^{1}$ Este ensayo propone que la novela, al otorgarle la voz a una gama de sujetos coloniales marginados, participa en un proyecto para cuestionar los discursos del colonialismo y de la modernidad que tradicionalmente han silenciado y excluido a estos grupos en los textos hispanoamericanos. García Márquez critica la fobia del Otro cultural y la violencia infligida contra ellos — que la colonia heredó de España—, al enfocar la represión manifestada por la Inquisición en Sierva María, una joven marquesita que vive en Cartagena de Indias a mediados del siglo dieciocho. ${ }^{2}$ Sierva María, quien se define como africana negra, es mordida por un perro rabioso en las calles de la ciudad. Mientras la niña nunca tiene síntomas de haber contraído la enfermedad, ni se muestra como víctima de posesión demoníaca, como se le acusa después, se convierte en el objeto de una cruel inquisición médica y religiosa que eventualmente la mata. La persecución de Sierva María se revela en este ensayo como dirigida contra la diferencia cultural en general y la africanía en particular, siendo ésta categorizada por la sociedad colonial de la novela como

*Una versión preliminar de este ensayo se presentó en el congreso del South Central MLA en New Orleans, 12-14 de noviembre, 1998.

${ }^{1}$ Me refiero aquí a la entrevista con Plinio Apuleyo Mendoza, en que García Márquez dice, refiriéndose a un viaje que hizo a Angola en 1978: "En América Latina se nos ha enseñado que somos españoles. Es cierto, en parte, porque el elemento español forma parte de nuestra propia personalidad cultural y no puede negarse. Pero en aquel viaje a Angola descubrí que también éramos africanos. O mejor, que éramos mestizos. Que nuestra cultura era mestiza, se enriquecía con diversos aportes. Nunca, hasta entonces, había tenido conciencia de ello" (El olor de la guayaba 54).

${ }^{2}$ El momento histórico de la novela es esencial para los temas de decadencia, mestizaje racial y represión indicados en este ensayo. La historia de Sierva María no tiene lugar en el siglo diecisiete como sugiere Rodríguez Vergara (127-29). 
manifestaciones patológicas. La novela histórica como género siempre ha hecho comentarios sobre la sociedad contemporánea, así como sobre el pasado que la informa y la moldea. En Del amor y otros demonios, García Márquez examina el legado del colonialismo y del racismo en Colombia y en Hispanoamérica, y sugiere que la diferencia cultural se crea a menudo a base del miedo y la intolerancia. Como consecuencia, la capacidad de contagiar o destruir a la sociedad que se atribuye al Otro revela frecuentemente la patología interna de esa misma sociedad. La patología que García Márquez ve en Colombia es la continua inhabilidad de reconocer las facetas de su constitución cultural, puesto que ese amor propio fue exorcizado por las injusticias de la esclavitud y la Inquisición.

LA “pos”-MODERNidAd y LA REESCRITURA DE AMÉRICA LATINA

La “retórica de la modernidad”, como la llama Carlos Alonso, que fue adoptada por escritores e intelectuales desde el siglo dieciocho en adelante, ha sido contrapuesta últimamente en la narrativa hispanoamericana por lo que Alonso identifica como una de las muchas facetas de la pos-modernidad. ${ }^{3}$ Hay una meta de naturaleza dual propuesta por la novelas históricas que cuestionan la modernidad en su propia construcción estética mientras vuelven a los orígenes de Hispanoamérica y reescriben también ese comienzo. Este proceso se considera necesario porque la región ni experimentó plenamente los beneficios materiales de la modernidad ni se sometió enteramente a sus impulsos homogeneizantes. Al contrario, “discourses regarded as 'modern' were appropriated by Spanish American intellectuals with the naïve hope of becoming modern in the process" (258). Puesto que la realidad hispanoamericana nunca coincidió con el discurso de la modernidad, insiste Alonso, siempre ha existido un mecanismo interno al texto que resiste ese discurso y, al mismo tiempo, una necesidad "to define simultaneously a space outside that rhetoric" (258). Dice Alonso:

Every Spanish American text is engaged at some level or another in this attempt to effect a cultural claim to exception from the demands of modernity, a claim that is the expression of a discursive will to power, an attempt to stave off the rhetorical disenfranchisement with which modernity threatened the Spanish American writer at every turn. It is a strategy designed to fashion a rhetorical foundation, to arrive at a position of rhetorical authority out of the difficult discursive situation outlined above; a stratagem to empower rhetorically the Spanish American writer in the face of modernity's threat to undermine the legitimacy of his discourse. (259) ${ }^{4}$

Con la novela histórica, los escritores hispanoamericanos han logrado cerrar el ciclo de esta larga tradición de una modernidad impuesta. Del amor y otros demonios se puede analizar productivamente dentro de este contexto, especialmente porque García Márquez

\footnotetext{
${ }^{3}$ Determinar la relevancia de una “pos”-modernidad en América Latina, donde la modernidad se ha obtenido en grados parciales y (disparates) ha sido problemático para algunos intelectuales. ${ }^{4}$ En su ensayo, Carlos Alonso considera la producción de El general en su laberinto como ejemplo de esta estrategia de contraposición a los discursos de la modernidad. Esta perspectiva es muy relevante para mi análisis de Del amor y otros demonios.
} 
participa tan explícitamente en un proyecto de reescritura. El prólogo de la novela explica que como periodista, en 1949, asistió a la demolición del convento de Santa Clara en Cartagena, durante la cual presenció la apertura de la tumba de la marquesita Sierva María de Todos los Ángeles, de doce años de edad y muerta hacía ya doscientos años. Cuando su cabellera cobriza y resplandeciente de veintidós metros de largo se escapa de la tumba, también escapa la historia colonial, junto a la tradición oral que repite la historia de una niña que se parece a Sierva María. ${ }^{5}$

La apertura de la tumba es la puerta metafórica que usa García Márquez para volver al pasado. ${ }^{6}$ Lo significante de la creación de la novela y todos sus personajes es la apelación al discurso popular y su participación en la revisión inventiva de la historia. En la construcción de la historia nacional, García Márquez ubica la autoridad no en un texto escrito, sino en el artefacto y la memoria oral. Las voces marginadas reciben prioridad dentro del texto de recreación colonial y en el contexto contemporáneo que supuestamente motiva el origen de la novela. ${ }^{7}$ Al yuxtaponer estas voces con la Inquisición que las silenció en el discurso oficial, García Márquez se compromete a socavar la retórica de la modernidad.

\section{DECADENCIA, INFILTRACIÓN E INFECCIÓN}

El espacio de la ciudad colonial en Del amor y otros demonios es un espacio de decadencia y ruina, habitado por personajes que de un momento a otro se convierten en fantasmas alienados y ambulantes de si mismos. La novela tiene lugar en Cartagena de Indias a mediados del siglo dieciocho, en el momento en que la ciudad ha sido desplazada por La Habana como el puerto principal de la trata de esclavos en Hispanoamérica. A pesar

\footnotetext{
5 “El maestro de obra me explicó sin asombro que el cabello humano crecía un centímetro por mes hasta después de la muerte, y veintidós metros le parecieron un buen promedio para doscientos años. A mí, en cambio, no me pareció tan trivial, porque mi abuela me contaba de niño la leyenda de una marquesita de doce años cuya cabellera le arrastraba como una cola de novia, que había muerto del mal de rabia por el mordisco de un perro, y era venerada en los pueblos del Caribe por sus muchos milagros. La idea de que esa tumba pudiera ser la suya fue mi noticia de aquel día, y el origen de este libro" (Del amor 11). Otro hecho relevante para el discurso popular es que la madrina negra de Sierva María, Dominga de Adviento promete el cabello de la niña a la Virgen María. El cabello de la niña no se debía cortar hasta el día de su boda, evento que, por supuesto, nunca ocurrió.

${ }^{6}$ Michael Palencia Roth afirma que la historia del prólogo no tiene base verídica (121, véase nota 13).

${ }^{7}$ Esta novela se escribió en 1994, cuando Colombia demostraba una preocupación aparente por la inclusión política y cultural de poblaciones marginadas y la preservación de sus culturas y lenguas. La constitución de 1990 contiene varios artículos que señalan la importancia de esta inclusión: Constitución Política de la República de Colombia, de 1991, con la Reforma de 1997, “Título I, Art. 7. El Estado reconoce y protege la diversidad étnica y cultural de la Nación colombiana. Art. 8. Es obligación del Estado y de las personas proteger las riquezas culturales y naturales de la Nación. Art. 10. El castellano es el idioma oficial de Colombia. Las lenguas y dialectos de los grupos étnicos son también oficiales en sus territorios. La enseñanza que se imparta en la comunidades con tradiciones lingüísticas propias será bilingüe”. La constitución se puede ver en su totalidad en el sitio de Internet: (http://www.bibliotecasvirtuales.com/biblioteca/Constituciones/Colombiana/constitucion.htm)
} 
del ímpetu reformador de los Borbones, España continuó ofuscada por los avances económicos y científicos de los otros imperios europeos. Dentro de las Américas, donde una conciencia criolla e independiente estaba siempre creciendo, esta disparidad de poder dejaba las colonias españolas a menudo a merced de ataques navales de los ingleses, y resultó en que gran parte del intercambio económico se trasladara de las colonias españolas a las inglesas. En la narrativa, los espacios físicos en varios estados de derrumbe repiten el abandono en que la colonia se encuentra. Por ejemplo, la casa de los padres de Sierva María, Don Ygnacio de Alfaro y Dueñas, segundo Marqués de Casalduero, y su esposa mestiza Bernarda Cabrera, está en ruinas, y flanqueada por un manicomio para mujeres. "La casa había sido el orgullo de la ciudad hasta principios del siglo. Ahora estaba arruinada y lóbrega...” (17). La prevalencia del contrabando, de los piratas ingleses y de los esclavos cimarrones, señalan la decadencia del imperio español y el control menguante en sus colonias. Bernarda, en sus días más vibrantes y emprendedores, hizo una fortuna con el contrabando de harina y esclavos. Ahora, por toda la región, los esclavos huyen al palenque de San Basilio y Bernarda se hunde en la adicción y la soledad. Frente a esta decadencia, en combinación con los ideales nacientes de la razón y el pragmatismo que pronto alimentarían la Ilustración, la Inquisición se esforzó por mantener el control sobre las acciones y pensamientos de sus sujetos coloniales. Durante esta época de transición, en la novela, todas las estructuras tradicionales de la legalidad y la religión parecen hundirse bajo el peso de su irrelevancia. Como Abrenuncio, el médico de Sierva María, le dice a Cayetano Delaura, el sacerdote que luego será el exorcista y amante de la niña, "Si usted conoce las debilidades de estos reinos, sabrá que las leyes no se cumplen por más de tres días” (163).

Sin embargo, la decadencia que rodea y “contagia” a Cartagena no se atribuye sólo a factores económicos. Se ubica en la podredumbre interna de los protagonistas que reflejan y también contribuyen al derrumbe de la ciudad colonial. Por todas partes se ven manifestaciones de enfermedad, locura y adicción que se mezclan con niveles de exilio y varias formas de esclavitud metafórica. ${ }^{8}$ Cuando el marqués, de joven, insiste en que se casará con Dulce Olivia, una loca que habita el manicomio de al lado, su padre lo exilia a las haciendas de la familia. Bernarda, en su esfuerzo para escaparse de su matrimonio estéril y manejar sus empresas de contrabando, se exilia a la plantación de azúcar, donde puede hundirse libremente en su adicción a las tabletas de cacao y la miel fermentada.

En medio de esta ciudad arruinada, las idiosincrasias de los varios personajes irónicos de García Márquez proveen un tono carnavalesco a la narración. En este paisaje polivocal surgen las voces que se oponen al imperio. Abrenuncio de Sa Pereira Cao, un judío portugués exiliado en las colonias españolas, es un médico educado y comprensivo que no cree ni en Dios ni en la ciencia. “'Los libros no sirven para nada,' dijo Abrenuncio de buen humor. 'La vida se me ha ido curando las enfermedades que causan los otros médicos con sus medicinas'”(41). Se niega a participar en el drama humano del amor y del sexo, pero entierra a su querido caballo de cien años de edad en tierra santa. Abrenuncio y el

${ }^{8}$ Véase R.A. Kerr para una discusión de los personajes exiliados (775); Michael Palencia Roth sugiere que endemoniar y esclavizar son temas relacionados en la novela: "Ambos procesos tienen que ver con la posesión, ya sea del alma, ya sea del cuerpo” (113). 
jesuita Cayetano Delaura son las voces más racionales de la historia, aunque el primero añora ser liberado de su razón y el otro se siente abrumado por su pasión. El obispo Toribio de Cáceres y Virtudes es un asmático que ha perdido su fe en el pasado. Sin embargo, irónicamente, es posiblemente el defensor más fanático de la Inquisición. Le dice al marqués, quien no cree en Dios: “Así que lo esencial no es que tú no creas, sino que Dios siga creyendo en ti” (76).

Mientras el obispo y el marqués son las figuras que deben representar la autoridad monolítica con más fuerza frente el reto al poder colonial, en realidad son personajes débiles. R.A. Kerr señala, por ejemplo, que los dos están a menudo reclinados o recostados: el marqués se retira a la soledad de su hamaca, mientras el obispo se mece para calmar su asma. Cuando el marqués intenta afirmar su autoridad, indica Kerr, su primer paso es el de restaurar el orden a su casa ruinosa (Kerr 733-36). De hecho, la casa es un símbolo que representa la sociedad y la colonia en general, y lo que hay que añadir aquí es que el marqués vive con el miedo constante de que lo ataquen o lo maten los esclavos africanos en su casa. Por esta razón tiene mastines para protegerse. Cuando decide encargarse de su casa, primero expulsa a los negros que se le han infiltrado en la mansión. ${ }^{9}$ Esta “infiltración” de los esclavos a la casa, o sea a un espacio que debe representar el poder colonial, es simbólico del socavamiento del orden establecido que tiene lugar en la ciudad entera. Consistente con el contexto histórico de la novela, el cual implica un control ibérico que disminuye frente a sus colonias heterogéneas, empieza ya en Del amor y otros demonios una transferencia del poder a sectores que no son masculinos, ni europeos ni criollos. ${ }^{10}$ Dominga de Adviento, “una negra de ley,” la mujer que cría a Sierva María, es sin duda la fuerza dominante de la casa hasta su muerte, e incluso después. Bernarda, una mestiza, es muchas veces más fuerte en carácter que su esposo criollo. Incluso a nivel de la sexualidad, ella lo domina: ella viola al marqués, casado ya antes, pero virgen todavía, para embarazarse. Además, Judas Iscariote, el amante negro y libre de Bernarda y el único hombre que ella realmente quiere, nunca se

${ }^{9}$ Después de la muerte de su primera esposa, doña Olalla de Mendoza, el marqués se queda solo. "Por primera vez solo en la tenebrosa mansión de sus mayores, apenas si podía dormir en la oscuridad, por el miedo congénito de los nobles criollos de ser asesinados por sus esclavos durante el sueño. Despertaba de golpe, sin saber si los ojos febriles que se asomaban por los tragaluces eran de este mundo o del otro. Iba en puntillas a la puerta, la abría de pronto, y sorprendía a un negro que lo aguaitaba por la cerradura. Los sentía deslizarse con pasos de tigre por los corredores, desnudos y embadurnados de grasa de coco para que no pudieran atraparlos. Aturdido por tantos miedos juntos ordenó que las luces permanecieran encendidas hasta el amanecer, expulsó a los esclavos que poco a poco se apoderaban de los espacios vacíos, y llevó a la casa los primmeros mastines amaestrados en artes de guerra" (55).

${ }^{10}$ Doris Sommer, en su lectura de $S a b$ de Gertrudis Gómez de Avellaneda, sugiere que la autora propone con su novela la necesidad de que el poder de la sociedad patriarcal, blanca y esclavista en Cuba durante el siglo diecinueve comience a pasar a nuevas manos, específicamente a las mujeres y a la gente de color (aunque Sab ocupa una posición algo distanciada de la cultura negra.) Según Sommer, lo que impide esa transferencia de poder es la institución de la esclavitud, porque prohibe la transcendencia del amor entre Carlota y Sab a un plano romántico que pudiera ser aprobado legalmente. Véasa capítulo cuatro de Foundational Fictions por Doris Sommer, "Sab C’est Moi” 114-37. 
somete al estatus social de la marquesa. Al contrario, ella es la que se transforma en la esclava metafórica de él. Así, la jerarquía tradicional de raza, género y poder se subvierte en la novela, demostrando la erosión de las estructuras sociales y raciales que sufrían la presión del aumento de mestizaje que ya venía ocurriendo en la región. ${ }^{11}$ Por un lado, el obispo lamenta este mestizaje y los obstáculos que produce para el catolicismo:

Habló de Yucatán, donde habían constuído catedrales suntuosas para ocultar las pirámides paganas, sin darse cuenta de que los aborígenes acudían a misa porque debajo de los altares de plata seguían vivos sus santuarios. Habló del batiburrillo de sangre que habían hecho desde la conquista: sangre de español con sangre de indios, de aquéllos y éstos con negros de toda laya, hasta mandingas musulmanes, y se preguntó si semejante contubernio cabría en el reino de Dios. A pesar del estorbo de su repiración y de su tosecita de viejo, terminó sin concederle una pausa al virrey:

“¿Qué puede ser todo eso sino trampas del Enemigo?”. (139)

Pero para las voces menos fanáticas, el mestizaje parece ser un mero hecho de la vida, el resultado de procesos históricos, muchas veces violentos, que han formado al individuo de descendencia mezclada:

“A mi edad, y con tantas sangres cruzadas, ya no sé a ciencia cierta de dónde soy”, dijo Delaura. "Ni quién soy".

"Nadie lo sabe por estos reinos", dijo Abrenuncio. "Y creo que necesitarán siglos para saberlo”. (153)

Cuando en la primera página de la novela Sierva María es mordida por un perro rabioso, las circunstancias del incidente y el evento en sí tienen que ver con africanos y la realidad africana en la colonia. La sirvienta mulata, de nombre irónico Caridad del Cobre, que acompaña a Sierva María al mercado, ha desobedecido las órdenes de su amo de no pasar más allá del Portal de los Mercaderes. Pero la actividad del puerto negrero la atrae y las dos entran en Getsemaní, el barrio de los esclavos negros y la gente libre de color. Más allá del puerto, matan a los sobrevivientes de un armazón de esclavos guineos por el miedo de que estén infectados con alguna enfermedad africana desconocida.

El barco de la Compañía Gaditana de Negros era esperado con alarma desde hacía una semana, por haber sufrido a bordo una mortandad inexplicable. Tratando de esconderla habían echado al agua los cadáveres sin lastre. El mar de leva los sacó a flote y amanecieron en la playa desfigurados por la hinchazón y con una rara coloración solferina. La nave fue anclada en las afueras de la bahía por el temor de que fuera un brote de alguna peste africana, hasta que comprobaron que había sido un envenenamiento con fiambres manidos (14).

11 “Although by the late eighteenth century the sociedad de castas was cracking up as a result of the continuing miscegenation that it tried to control, Jaramillo Uribe contends that there was also a period of retrenchment as the white elite, American creole and Spanish, tried to defend its position against encroachments by the mestizos” (Wade 9). Véase Jaime Jaramillo Uribe. Ensayos sobre historia social colombiana. 
La transgresión de la desobediencia de la sirvienta mulata, el espacio del barrio negro, y la violencia contra los africanos por miedo a que estén infectados y sean agentes infecciosos, crean el escenario para la mordida. Es significativo que los cuerpos africanos, flotando y llevados a la orilla por la marea, se niegan a conspirar en la borradura de la violencia que se ha cometido contra ellos. Finalmente, la misma mordida funciona como un indicio más de Sierva María como miembro de una comunidad africana: la niña es una de las cuatro personas mordidas ese día; todos los otros son esclavos negros. Dos han desaparecido y se sospecha que reciben ayuda de los curanderos en el palenque de San Basilio. Una quinta persona, un mulato infectado por la saliva del perro, sufre las últimas etapas de la enfermedad en un hospital, amarrado a un poste.

Sierva María es por nacimiento una mestiza que pertenece a la nobleza criolla. Sin embargo, se debe recordar que Sierva María no es criada por su madre sino por Dominga de Adviento. Dominga, una negra con un carácter de hierro, funciona como intermediaria entre la casa de los amos blancos y el patio de los esclavos, entre el cristianismo y la santería. Dominga es al mismo tiempo agente y producto de la transculturación y el sincretismo, un símbolo del fracaso del proyecto colonial de la homogeneización. "Se había hecho católica sin renunciar a su fe yoruba, y practicaba ambas a la vez, sin orden ni concierto. Su alma estaba en paz, decía, porque lo que le faltaba en una lo encontraba en la otra.” (19) Dominga, como madrina, instruye e inicia a Sierva María en la santería, adornándola con collares de los dioses africanos y mandando que le pinten la cara de negro. Sierva María, alienada de su propia familia, crea su propia identidad dentro de este ambiente. Se bautiza María Mandinga, duerme y come en los barracones, habla tres lenguas africanas, y canta y baila con los esclavos. "En aquel mundo opresivo en el que nadie era libre, Sierva María lo era: sólo ella y sólo allí. De modo que era allí donde se celebraba la fiesta, en su verdadera casa y con su verdadera familia” (19). ${ }^{12}$

Algunos críticos han propuesto que Sierva María es una figura híbrida que une las culturas europea y africana y existe como un personaje liminal o de fronteras. ${ }^{13} \mathrm{Sin}$ embargo, mientras Sierva María pertenece por herencia económica y cultural a la nobleza criolla, se autodefine como negra africana. La identidad racial se construye desde adentro y desde afuera, y Sierva María/María Mandinga fabrica la suya como negra africana. ${ }^{14}$ Incluso sus padres la reconocen como tal. La madre, quien la teme y la detesta, afirma: “'Lo único que esa criatura tiene de blanca es el color'” (63). Y cuando su padre intenta reintegrarla a la vida de la casa después de que aprende de la mordida y sus posibles consecuencias, "Trató de enseñarla a ser blanca de ley, de retaurar para ella sus sueños fallidos de noble criollo, de quitarle el gusto del escabeche de iguana y el guiso de

\footnotetext{
${ }^{12}$ Se podría argüir que Sierva María disfruta de un grado más alto de libertad específicamente porque no es negra. A fin de cuentas, no sufre la opresión y las miserias de la esclavitud ni las consequencias sicológicas que acompañaban el racismo y el colonialismo, como las indicadas por Franz Fanon en su Black Skin, White Masks.

${ }^{13}$ Véase, por ejemplo, el artículo de Eugenia Muñoz.

${ }^{14}$ Michael Palencia Roth está de acuerdo con esta perspectiva: "Aunque racialmente europea y mestiza, Sierva María de Todos los Ángeles es espiritualmente africana. Es decir, aunque en ella se mezclan simbólicamente las sangres de las tres culturas más importantes de Colombia, la base de su salvación, la base de su beatificación simbólica y estética, es principalmente la africana” (121).
} 
armadillo. Lo intentó casi todo, menos preguntarse si aquél era el modo de hacerla feliz" (66). Pero, en un movimiento contrario al de los esclavos que infiltran la casa, Sierva María se escapa de ella y regresa a los barracones, donde se siente más en su ambiente. Además, sea en el patio de los esclavos, en la casa de sus padres o en el convento de Santa Clara, adonde la mandan para curar su supuesta posesión demoníaca, los esclavos africanos y criollos siempre la reconocen como una de los suyos por medio de los símbolos culturales, como los collares que lleva y su conocimiento de las lenguas y bailes africanos.

Es simbólico que en la novela de contra-modernidad de García Márquez la protagonista central haga una mudanza transcultural y transracial desde la blancura a la negrura. Como indica Peter Wade en su libro Blackness and Race Mixture, el proyecto nacional de consolidación racial en Colombia históricamente ha promovido el mestizaje a base del blanqueamiento, tanto cultural como biológicamente (11). Los verdaderos procesos de mestizaje a lo largo de la historia colombiana, a pesar de esta preferencia hegemónica por el blanqueamiento, han sido mucho más complejos. Wade señala dos fenómenos predominantes y determinados a base de la región: la asimilación y el aislamiento. El primero es una integración de afrocolombianos en la cultura iberocolombiana, y la segunda es una estrategia voluntaria, o parcialmente impuesta, de aislamiento (6). Los dos procesos pueden contribuir a una invisibilidad aparente de afrocolombianos en la sociedad dominante en Colombia. Wade añade que la negrura se define tanto desde adentro como desde afuera, y que la geografía, la clase y la política de identidad son todos factores que contribuyen a determinar quién se considera negro. ${ }^{15}$ Es llamativo que lo que sucede en el caso de Sierva María sea lo contrario del blanqueamiento, o sea, un proceso voluntario de ennegrecimiento, por lo menos a nivel cultural y espiritual. Este posicionamiento destruye la jerarquía tradicional de razas y contribuye a la subversión de estructuras coloniales.

Parece casi seguro que después de varias semanas, Sierva María ya no está en peligro de contraer la rabia. De hecho, en ningún momento muestra síntomas de la enfermedad. Pero el sentido pervertido de honor de su madre junto con el terror de su padre a la enfermedad, especialmente después de haber presenciado la locura del mulato amarrado al poste, motivan al marqués a dejar a la niña bajo el cuidado de las llamadas autoridades médicas y religiosas de la ciudad. Abrenuncio, viendo que la herida ya se ha cerrado, le asegura al marqués que no es muy probable que la niña ahora contraiga la rabia. Su razón transciende el mero empiricismo cuando sugiere que la niña sólo necesita bondad y ternura: "No hay medicina que cure lo que no cura la felicidad.” (47) Pero, cuando Sierva María sufre una leve fiebre, causa pánico en el marqués, y las visitas a una plétora de médicos inflaman la herida con tratamientos innecesarios y a veces absurdos. Ante el apremio del obispo, quien sugiere que la niña pudiera estar poseída por el demonio, el marqués deja a su hija en el convento de Santa Clara. Se debe notar que sólo cuando los médicos creen ver una patología es cuando empieza a supurar la herida con esos tratamientos. Y es cuando la Abadesa Josefa Miranda y el obispo buscan la posesión demoníaca en la niña que la encuentran, atribuyéndole fenómenos naturales e incidentes inexplicables en el convento a la supuesta posesión de Sierva María.

${ }^{15}$ Véase los tres primeros capítulos del libro de Wade. 
Como indica Sander Gilman en su Difference and Pathology, y ejemplifica para el racismo en el siglo diecinueve, la conexión entre la negrura y la patología ha existido desde la Edad Media. Tradicionalmente, la negrura ha indicado enfermedad y aberración. Sexualmente, ha significado desvío y promiscuidad. La locura también se ha caracterizado, incluso en el siglo veinte, como relacionada esencialmente a la negrura. ${ }^{16}$ Claramente, el acto de situar la patología en el otro funciona como una estrategia de poder. Según Gilman, la locura o la enfermedad del otro es lo que define la cordura o la salud del grupo:

The group is embodied with all of the positive associations of the self. The Other is the antithesis of the self and is thus that which defines the group (that which has robbed the self of power but in exchange provided it with protection). The Other is therefore both ill and infectious, both damaged and damaging. (129-30)

O, como afirma V.Y. Mudimbe:

The African has become not only the Other who is everyone else except me, but rather the key, which, in its abnormal differences, specifies the identity of the Same. (Invention 12)

No es coincidencia que la historia misionera del siglo diecisiete escrita por el jesuita Alonso de Sandoval y que promovía la conversión de africanos en Cartagena de Indias se titulara De instauranda Aethiopum salute. El establecimiento de la salud del africano era una propuesta de curar espiritualmente más que físicamente, y esta misma prioridad por la salud del alma se repite cuando el obispo le dice al marqués: "Por fortuna, aunque el cuerpo de tu niña sea irrecuperable, Dios nos ha dado los medios de salvar su alma” (79). Y cuando le nombra a Cayetano Delaura como el exorcista de Sierva María, “Te encomiendo la salud de la niña” (103). Dice V.Y. Mudimbe:

An evolutionary thesis expresses the conversion from savagery and Satan's darkness to the light of civilization and God's kingdom. The transformation is sometimes described as the introduction or restoration of health in a sick universe, the establishment of order in a world of disorder, madness, corruption, and diabolical illusions. (Invention 52)

La patología que se le inscribe a Sierva María, o sea, la sospecha de que ella esté contagiada con la rabia, lo cual se convierte en la posesión demoníaca, es en realidad la enfermedad de los que la rodean. La patología de la sociedad colonial de la novela es tan literal como en sus manifestaciones de miedo e intolerancia. A fin de cuentas, esa enfermedad es la incapacidad de amar al otro y la negación de la sociedad de dejar existir un amor por el otro. El obispo sufre de asma, y lo que es más significativo, de un exceso de bilis negra y melancólica. Su propia fe cuestionada, junto al miedo a lo demoníaco, lo

${ }^{16}$ Véase, sobre todo, capítulo cinco, "On the Nexus of Blackness and Madness.” En el siglo diecinueve, se decía que el motivo para que los esclavos se huyeran era una enfermedad que padecían que se llamaba “drapetomania”; y una enfermedad parecida, “dysaethesia aethiopis” supuestamente los hacía desobedientes y recalcitrantes (138). 
llevan a sugerir que Sierva María no tiene rabia sino que está poseída: “entre las numerosas argucias del demonio es muy frecuente adoptar la apariencia de una enfermedad inmunda para introducirse en un cuerpo inocente” (76). Mientras tanto, el marqués y su esposa se pudren en vida en medio de los espacios decadentes que los contienen, ella en su adicción, él en su alienación. Cada uno se había enamorado anteriormente con un individuo que tiene su existencia más allá de las fronteras de un compañero aceptable y legal. Dulce Olivia era el verdadero amor del marqués, y él había intentado débilmente defender su amor frente a la negativa de su padre de aceptarlo, comentando: "Ningún loco está loco si uno se conforma con sus razones” (50). Pero, rechazó su propio amor bajo lo que era para él el peso insoportable de descartar la tradición y el poder de la familia. Bernarda, había encontrado el amor absoluto en Judas Iscariote, pero ella no supo hacer el sacrificio necesario de honor y estatus para disfrutarlo plenamente. Se disfrazaron en inversiones carnavalescas de sí mismos para poder aparecer juntos en público. Para muchos personajes que existen en una decadencia social y personal, el aferrarse inútilmente a tradiciones que ya no tienen relevancia, como la ortodoxia religiosa y la pureza de sangre, parece ser la única fuente de sentido en la novela. Sin embargo, la naturaleza fársica de tales nociones respetadas se revela a cada paso. El más amable de los exorcistas de Sierva María, por ejemplo, un cura mulato llamado Tomás de Aquinas de Narváez, reinventó su propio pasado: "Había nacido aquí, hijo de un procurador del rey que se casó con su esclava cuarterona, y había hecho su noviciado en el seminario local una vez demostrada la limpieza de su linaje por cuatro generaciones de blancos” (178).

Mientras los otros personajes de la novela se preocupaban por afirmar la pureza de su sangre "blanca” y medir su valor por medio de la religión y la nobleza, Sierva María se hizo negra africana. Llegó a ser el objeto de la furia de la Inquisición no porque estaba enferma, ni porque estaba poseída, sino porque era diferente. Su diferencia era su africanía. Como ninguno de sus padres la amaba cuando era niña, fue expulsada de la casa, un gesto cargado de significado simbólico, y encontró el amor en otra parte, entre los esclavos. En consecuencia, su familia y la sociedad en general la perciben como hermética y rara, pero la comunidad africana siempre la recibe cariñosamente. La niña es invisible en la casa de sus padres y en el convento donde la mandan para ser exorcizada. La abadesa no la ve sentada en el patio del convento el día de su llegada. Bernarda le cuelga una campana por el cuello para no asustarse de la presencia de la niña. Sierva María, quizás como metonimia por el pueblo de origen africano en la colonia, es el producto del sistema social en que nació y se crió, pero todavía permanece extraña, peligrosa, hermética, invisible y misteriosa a ese sistema, no porque sea así implícitamente, sino porque la definen como tal, aplicándole los mismos parámetros que a todos los que retan las fronteras de la "mismidad". El esclavo no puede ser igual al yo, porque tiene que permanecer esclavo. Sierva María no puede ser igual porque es demasiado rara, y su rareza es africana. Su cuerpo es análogo a los cuerpos de los africanos que surgen a la superficie del agua, asesinados porque eran potencialmente infecciosos. Cuando su cabellera se vierte desde la tumba, recuerda su vida truncada porque no se debía cortar el pelo hasta el día de su boda - día que nunca llega. Su sufrimiento se niega a silenciarse, del mismo modo que los cuerpos de los africanos rechazan la borradura y atestiguan la violencia cometida contra 
ellos. Como parte del proyecto esterilizante y homogeneizante, la violencia se justifica como necesaria, porque lo que se expulsa como externo al ser, se considera contagioso e infeccioso. La única esperanza para Sierva María desde una perspectiva dominante, entonces, es la misma que para un esclavo negro: la salvación del alma. Su cuerpo, como el cuerpo negro, ya está enfermo y condenado.

El único individuo que se da cuenta de la verdadera “enfermedad” de Sierva María es su exorcista y amante, Cayetano Delaura. Le dice a Abrenuncio: "creo que lo que nos parece demoníaco son las costumbres de los negros, que la niña ha aprendido por el abandono en que la tuvieron sus padres” (124). Para Delaura, Sierva María es lo desconocido del libro prohibido que nunca pudo terminar porque la inquisición vetó su lectura. (Fue una novela de caballerías, el Amadís de Gaula). Sierva María, representada por su sexualidad y africanía, es análoga al misterio del libro prohibido para el cura. La Inquisición y la sociedad que la tolera han impuesto los límites de la experiencia humana, incluso en el amor. Cuando se enamora de la niña, Delaura primero se tortura y luego se entrega a su propia pasión y delirio. Ella, por su parte, le coloca uno de sus collares de santería, el de Oddúa. ${ }^{17}$ De nuevo, la novela presenta la posibilidad del amor entre el yo y el Otro, y otra vez se frustra. Como con el marqués y Bernarda anteriormente, el amor de Delaura es insuficiente ante la sociedad que lo constriñe. Él y Sierva María empujan los límites de su pasión, pero permanecen vírgenes. Sierva María lo invita a huir con ella al palenque de San Basilio donde podrían estar juntos, pero se niega. Ingenuamente, Delaura siente que puede haber una forma legítima para estar juntos: “Confiaba mas bien en formalismos legales” (183). Su voluntad es demasiado débil para romper las barreras de la diferencia. Irónicamente, son las formalidades legales del Santo Oficio las que lo castigan duramente por sus transgresiones y lo condenan a una vida de trabajo entre leprosos.

EL AMOR Y LA FICCIÓN FUNDACIONAL COLOMBIANA

Del amor y otros demonios socava la primacía del texto escrito mientras media entre la realidad y la ficción, el mito y la historia, el pasado y el presente. García Márquez vuelve al pasado colonial para ubicar la fuente de la patología indicada en este ensayo, una enfermedad de la que Colombia todavía sufre: la incapacidad de amar al africano como el yo, o amar al africano dentro del yo. El resultado dentro de la novela es el de una "ficción fundacional" fracasada, o la naturaleza imposible del amor interracial, entre negro y blanco, europeo y africano - a nivel de la nación. La ubicación de la “raza”, específicamente la africanía negra, dentro de una historia textual que es colonial, colombiana e hispanoamericana a la vez, es así parte de un proyecto en que García Márquez redefine y reescribe esa historia con mucho sentido de la ironía y de la tragedia.

\footnotetext{
${ }^{17}$ No tengo referencia que exista una diosa yoruba llamada Oddúa. Existe Oddudúa, esposa de Obatalá, uno de los cinco orishas principales. Incidentalmente, Oddudúa era conocida por sus aventuras extramatrimoniales, hasta que Obatalá la encontró y le arrancó los ojos.
} 
El amor ha sido identificado como metáfora de la enfermedad en la obra de García Márquez, particularmente El amor en los tiempos del cólera (W. Faris; J. McNiff y M. Burrell). El amor es una enfermedad que infecta, e incluso mata, a los que la contraen. De hecho, al final de Del amor y otros demonios, Sierva María supuestamente ha muerto de amor: "La guardiana que entró a prepararla para la sexta sesión de exorcismos la encontró muerta de amor en la cama con los ojos radiantes y la piel de recién nacida” (198). En la obra de García Márquez, el amor es en general problemático y la diferencia se puede caracterizar fácilmente como la diferencia que existe entre todos los seres humanos que viven como islas, alienados el uno del otro de una forma u otra. Pero en Del amor y otros demonios, lo que impide el éxito del verdadero amor no es sólo un ambiente de alienación existencialista, sino también el racismo y la opresión de una sociedad colonial que previene que los individuos logren disfrutar el amor. La ironía, claro está, es que ningún personaje de la élite cartagenera colonial de García Márquez sea un participante completo y creyente en sus sistemas de exclusión y represión. Al contrario, cada uno se ha construido o revisado para caber dentro de los parámetros del poder colonial, con la excepción de dos personajes: Abrenuncio y Sierva María. La burla de García Márquez de las identidades inventadas por sus personajes, se refleja en su disponibilidad destructiva de atribuir tanta autoridad, tanto textual como cultural, al discurso del colonialismo. Las actas de la Inquisición, por ejemplo, se retratan como invenciones de la imaginación, usadas para explicar lo inexplicable en un mundo donde lo absurdo y lo mágico son supremos.

Quince años antes de publicar Del amor y otros demonios, García Márquez publicó Relato de un náufrago, otra novela histórica con supuestos orígenes periodísticos. Aquí, vemos con mayor claridad la invisibilidad de los afrocolombianos que el autor problematiza en la novela más reciente. En 1955, cuando Luis Alejandro Velasco, el marinero colombiano náufrago, por fin se arrastra a la orilla del mar después de diez días a la deriva en una balsa, no tiene la mínima idea de adónde ha llegado. Su incertidumbre aumenta cuando ve al primer ser humano que encuentra:

Era una muchacha negra, increíblemente delgada, joven y vestida de blanco. Llevaba en la mano una ollita de aluminio cuya tapa, mal ajustada, sonaba a cada paso. “¿En qué país me encuentro?”, me pregunté, viendo acercarse por el camino a aquella negra con tipo de Jamaica. Me acordé de San Andrés y Providencia. Me acordé de todas las islas de las Antillas. Aquella mujer era mi primera oportunidad, pero también podía ser la última “¿Entenderá castellano?” (96)

La llama en inglés ("Hello! , Help me!), pero la muchacha huye, asustada. El hombre que encuentra a Velasco es el que después lo ayuda. Después de identificarse, Velasco le hace una pregunta esencial: “¿Qué país es éste?

Y él, con una extraordinaria naturalidad, me dio la única respuesta que yo no esperaba en aquel instante: “Colombia'” (98).

El hecho de que el marinero no logre identificar su propio país por la inesperada (para él) presencia de sus habitantes negros, atestigua una invisibilidad social y geográfica que persiste de alguna forma hasta hoy en día. Pero lo que García Márquez parece señalar en Del amor y otros demonios es que la posibilidad del amor — amor nacional, reconciliación 
racial - siempre ha existido en la sociedad colombiana, aun cuando no se haya obtenido con éxito todavía. Sierva María, se debe recordar, tuvo éxito — se convirtió en el Otro. La marginalización del otro durante el período colonial no era simplemente el resultado de las circunstancias —era, de algún modo, por designio. La categorización del africano como enfermo, loco o poseído era una estrategia de dominación y una reafirmación de la normalidad blanca. El concepto de nación siempre se ha basado en construcciones de raza e identidad que siempre están en flujo, de quiénes se incluyen y quiénes se excluyen; de lo que se esconde, y de lo que no; y finalmente, de lo que se escribe, y de lo que no. Y si la nación es una invención en términos tanto reales como discursivos, y la voluntad de crear una sociedad pertenece al pueblo que la crea, entonces la posibilidad de reescribir la nación todavía existe. Con esta novela, García Márquez intenta reescribir la nación discursivamente e invita a que otros la escriban a la vez, señalando siempre el diálogo textual que existe entre el pasado y el presente, lo histórico y lo real, lo visto y lo que queda por ver.

\section{Bibliografía}

Alonso, Carlos J. “The Mourning After: García Márquez, Fuentes and the Meaning of Postmodernity in Spanish America”. MLN 109/2 (March 1994): 252-67.

García Márquez, Gabriel. Del amor y otros demonios. Bogotá: Editorial Norma, 1994. El amor en los tiempos del cólera. Bogotá: Editorial Oveja Negra, 1985.

El olor de la guayaba: Conversaciones con Plinio Apuleyo Mendoza. Bogotá: Editorial Oveja Negra, 1982. Relato de un náufrago. Bogotá: Editorial Oveja Negra, 1979.

Fanon, Frantz. Black Skin, White Masks. Charles Lam Markmann, trad. Nueva York: Grove, 1967.

Faris, Wendy B. "Love in the Times of Proust and García Márquez". Love, Sex and Eroticism in Contemporary Latin American Literature. Alun Kenwood, ed. Melbourne: Voz Hispánica, 1992. 129-42.

Gilman, Sander L. Difference and Pathology: Stereotypes of Sexuality, Race and Madness. Ithaca: Cornell University Press, 1985.

Kerr, R. A. "Patterns of Place and Visual-Spatial Imagery in García Márquez’s Del amor y otros demonios”. Hispania 79 (December 1996): 772-80.

McNiff, John and Mary Burrell. "The Thematic of Love as Disease in Gabriel García Márquez’s Love in the Time of Cholera”. Likha 12/2 (Philippines, 1990-91): 47-70.

Mudimbe, V.Y. The Invention of Africa. Bloomington: Indiana University Press, 1988.

Muñoz, Eugenia. "La verdad en un caso de segregación e hibridación cultural en Del amor y otros demonios de Gabriel García Márquez”. Apuntes sobre literatura colombiana. Carmenza Kline, comp. Bogotá: Ceiba Editores, 1997. 95-107.

Palencia-Roth, Michael. “Del amor y otros demonios: tragedia inquisitorial, beatificación africana”. Apuntes sobre literatura colombiana. Carmenza Kline, comp. Bogotá: Ceiba Editores, 1997. 111-22. 
Rodríguez Vergara, Isabel. Del amor y otros demonios de Gabriel García Márquez: Incincerando la colonia”. Apuntes sobre literatura colombiana. Carmenza Kline, comp. Bogotá: Ceiba Editores, 1997. 125-36.

Sandoval, Alonso de. Un tratado sobre la esclavitud (De instauranda Aethiopum salute, 1627). Enriqueta Vila Vilar, trad. Madrid: Alianza Editorial, 1987.

Sommer, Doris. Foundational Fictions: The National Romances of Latin America. Berkeley: University of California Press, 1991.

Wade, Peter. Blackness and Race Mixture: The Dynamics of Racial Identity in Colombia. Baltimore: The Johns Hopkins University Press, 1993. 